\title{
PHENOTYPIC DIVERSITY OF JERUSALEM ARTICHOKE (Helianthus tuberosus L.) GERMPLASM PRESERVED BY THE CANADIAN GENEBANK
}

\author{
Axel Diederichsen ${ }^{*}{ }^{* *}$
}

Plant Gene Resources of Canada, Agriculture and Agri-Food Canada, 107 Science Place, Saskatoon, SK, S7N OX2, Canada

Received: March 23, 2010

Accepted: August 10, 2010

\begin{abstract}
SUMMARY
Jerusalem artichoke (Helianthus tuberosus L.) originated from the eastern United States and Mexico. Although considerable breeding efforts were made in Europe, the former Soviet Union, and to some degree in Canada, the species remains a neglected crop. Comprehensive characterization data of the genetic resources preserved in different genebanks is rare. A total of 162 Jerusalem artichoke accessions were preserved by Plant Gene Resources of Canada (PGRC) in 2006. This material was agrobotanically characterized in the growing seasons of 2006 and 2008 at Saskatoon, Saskatchewan, Canada. The results of 158 accessions grown in both years were compared. The assessments of variability of 13 rated and 10 measured descriptors for leaf, stem, tuber and phenological characters documented a wide range of phenotypic variation. Repeatability of assessments between the years was generally low, indicating a strong environmental influence on phenotypic diversity. Earliness of flowering, tuber width, tuber weight, tuber shape, tuber epidermis coloration and below-ground growth habit (tubers clustered vs. spread) were the most informative characteristics for describing variation among Jerusalem artichoke accessions. Leaf dimensions and leaf margin serration could also be used to distinguish extreme genotypes. A suggestion for categorizing the PGRC collection into large-tuber and primitive material based on single tuber weight and tuber width is made. Six categories of tuber types based on tuber color and tuber shape are presented.
\end{abstract}

Key words: characterization, Helianthus tuberosus L., Jerusalem artichoke, phenotypic variation, plant genetic resources, topinambour

* Corresponding author: Phone:+1-306-956 28 39; Fax:+1-306-956 72 46; e-mail: axel.diederichsen@agr.gc.ca

** Address after April 1, 2010: Nordic Genetic Resource Center, Box 41, SE-230 53 Alnarp, Sweden; Phone: +46-40-53 66 40; Fax: +46-40-53 66 50; e-mail: axel.diederichsen@nordgen.org 


\section{INTRODUCTION}

Jerusalem artichoke (Helianthus tuberosus L.) and sunflower (H. annuus L.) are the only important cultivated food plants that trace their prehistoric domestication to continental North America (Heiser, 1978). The eastern United States and Mexico are the areas of origin for $H$. tuberosus (Wein, 1963). Some authors referred to Jerusalem artichoke as being native also in Canada (Swanton et al., 1992). Munro and Small (1997) stated that plants found at wild or ruderal sites in Canada would be escapes from cultivation. While utilization of $H$. annuus by North American Indians seems well proven, it is unclear whether $H$. tuberosus was used only from wild plants or whether it had already been domesticated when encountered in the region of Massachusetts by Samuel de Champlain in 1605 (Heiser, 1978). Both Helianthus species were improved through selection and breeding in Europe after they had been introduced there (Wein, 1963; Pas'ko, 1974). Interspecific hybrids between these two species have been made and are cultivated as tuber plants (sunchokes) or used in sunflower breeding programs (Pas'ko, 1974; Heiser, 1978). While sunflower became an important source of vegetable oil in the world, Jerusalem artichoke, also known as topinambour, has remained a cultivated plant of marginal importance. It is questionable whether this "unloved vegetable" (Parameswaran, 1994) or "bad boy crop" (Johnson, 2010) has still a "Cinderella event" in its future.

During food shortages in times of war $H$. tuberosus received more attention by scientists and farmers because of its multiple uses as a vegetable, medicinal plant, forage plant and source for biofuel (Kays and Nottingham, 2008). The energy crisis of the 1970s motivated research on Jerusalem artichoke for biofuel as the aboveground plant biomass and the tubers can be used for this purpose (Hergert, 1991). The most intense breeding was conducted in the former Soviet Union (Pas'ko, 1974) while less attention was paid in other countries (Frese et al., 1987). The high content ( $15 \%$ of fresh matter) of the carbohydrate inulin (fructose polymers of 2-70 fructose units) in the tubers make it an important source of fructose for the healthfood industry (Fuchs, 1993). Other species from the Asteraceae family used for this purpose are Cichorium intybus L. and Dahlia pinnata Cav. The use of Jerusalem artichoke as an exotic vegetable has ensured preservation of this species by hobby gardeners and biodiversity enthusiasts in Canada and other countries (Munro and Small, 1997). Groups such as Seed Savers in the USA or Seeds of Diversity in Canada have contributed to preserving this crop (Joubert, 2001). The threat of global climate change reinforces the concept that Jerusalem artichoke is a highly productive low-input crop. Tuber yields of up to $75.5 \mathrm{t} / \mathrm{ha}$, and above-ground fresh green matter of up to 120 t/ha have been reported (Pas'ko, 1974).

The recently published monograph by Kays and Nottingham (2008) is the most comprehensive source of information on all aspects of the biology, agronomy and breeding of $H$. tuberosus. However, only a few overviews of the diversity existing in 
Jerusalem artichoke have been published. Pas'kov (1974) provided the most comprehensive description of ranges of variation of stem, leave, flower and tuber characteristics to date and distinguished ten cultivar types of Jerusalem artichokes among 72 cultivated clones. Later, Pas'kov (1987) enhanced the classification to 15 cultivar types based on studying 260 accessions. This latter study included wild material and was conducted at the Maikop Research Station of the N.I. Vavilov Institute, located close to the Caucasian mountains, south Russia. From a grower's perspective, Klokheid (2002) suggested a distinction of four groups based on tuber shape, tuber color, tuber epidermis thickness and below-ground growth habit. He refers to $H$. tuberosus as sunroot.

Specific evaluations for a smaller number of clones were provided by various authors investigating agronomic and chemical traits. Le Cochec (1990) described variation among 15 clones and reported a low heritability for yield and high heritability for phenological characters. Seiler (1993) evaluated 10 clones for their forage and tuber yields demonstrating that the cultivated clones were superior to the wild material. Kays and Kultur (2005) described phenological variation of flowering date and duration for 190 accessions grown in Georgia, USA. Chubey and Dorrell (1974) assessed eight lines for reducing sugar content and found a range from 13.2 to $27.7 \%$ in fresh tubers with cultivated material having lower reducing sugar content but a higher proportion (80.6\%) of fructose than wild lines $(75.3 \%)$. Kiehn and Chubey (1993) assessed the yield potential of 30 accessions as ranging from 4.4 to 76.5 t/ha for western Canada, exceeding the yields reported by Pas'ko (1974). They showed that later maturing material was inclined to have higher yield, whereas carbohydrate content was not associated with earliness.

For research or breeding of $H$. tuberosus it is essential to have access to genetically diverse germplasm. The Food and Agricultural Organization lists $468 \mathrm{H}$. tuberosus accessions preserved in genebanks around the world (FAO, 2009). Major holdings with more than 100 accessions exist in Canada, Serbia, Germany and the United States. Another large collection is maintained in France (Kays and Nottingham, 2008). A collection of more than 260 accessions was preserved in the former Soviet Union during the 1980s (Pas'ko, 1987).

The Canadian collection which presently gathers 160 accessions is relatively large. It was assembled at the Morden Research Centre of Agriculture and AgriFood Canada during the 1970s. The collection was transferred to the Canadian National Genebank, Plant Gene Resources of Canada (PGRC), in 2000. It is preserved as a field collection at the Saskatoon Research Centre in Saskatchewan. For enhanced utilization and preservation of the collection, it is essential to provide basic agronomic characterization data describing the material. This study summarizes descriptive data of the germplasm preserved by PGRC. The objective of this paper was to survey the diversity available in the PGRC collection for improved collection management and utilization of the germplasm. An attempt is made to give a 
HELIA, 33, Nr. 53, p.p. 1-16, (2010)

summarizing overview of the variability of Jerusalem artichoke and to elaborate the usefulness of the applied descriptors for categorizing the germplasm.

\section{MATERIAL AND METHODS}

In 2000, PGRC obtained from the Agriculture and Agri-Food Canada Morden Research Centre 171 samples of Jersualem artichokes. In 2004, four additional lines were obtained from another Canadian source (T. Klokeid, Salt Spring Island, British Columbia) resembling the four groups described by Klokeid (2002). In 2006, characterization data were collected on 162 accessions, of which 24 were cultivars from different countries (former USSR 14 accessions, France 2, USA 3, Canada 1, Germany 1 and unknown 3). Breeding lines were represented by 42 accessions mostly originating from the Morden Research Centre and 90 accessions were of unknown improvement status, most of them collected from ruderal sites in Manitoba, Canada. These accessions are probably escapes from former cultivation. The field genebank was established at the Saskatoon Research Farm $\left(52^{\circ} 10^{\prime} \mathrm{N}\right.$, $106^{\circ} 41^{\prime} \mathrm{W}$; elevation: $501 \mathrm{~m}$ ) on loamy, dark chernozemic soil. Each single plot of Jerusalem artichoke was started from 5-7 tubers planted in hills with five meters distance between the centers of the hill plots (Figures $1 \mathrm{~A}$ and B). A strip of 1-2 m soil between the plots was roto-tilled twice a year to control weeds and to cut stolons that would spread to neighboring plots. During the growing season, hand weeding of the plots was conducted as required. In the third growing season, a new plot area was started from tubers collected from the existing planting. Once this second nursery was well established, a third nursery was planted and the oldest nursery was abandoned. This protocol has been maintained so that at any time there were always two plots of each Jerusalem artichoke accession in the field. The older plot served as a back-up for re-filling plots in case an accession failed to establish in the recent planting. In addition, during autumn, five to ten tubers were collected from each plot and stored in polyethylene bags at about $4^{\circ} \mathrm{C}$. These tubers served as additional back-up. In 2009, the fifth nursery of the Jerusalem artichoke plots was established. In autumn 2009, PGRC had 159 plots in the field planting, because 16 accessions of the original collection had been lost over time. Most of these losses occurred during the cold winter 2002-2003. Some losses were due to field infection with Sclerotinia and Fusarium root rot. To date, cryopreservation has not been used as a standard protocol to preserve the PGRC collection, although the techniques have been successfully developed on selected material (Volk and Richards, 2006). It would be desirable to secure the long-term preservation of the PGRC collection by additional cryopreservation.

A descriptor list for assessing vegetative plant parts (leaves, stems), generative organs (tubers) and one phenological trait (earliness of flowering) was applied to the entire collection. A rating scale was applied for 13 descriptors, (Table 1) and for 10 characters measurements were conducted (Table 2). The quantitative measure- 
Table 1: Variation of qualitative, rated characters in Jerusalem artichoke

\begin{tabular}{|c|c|c|c|c|c|}
\hline \multirow[b]{2}{*}{ Character } & \multirow[b]{2}{*}{ Code and rating scale } & \multicolumn{4}{|c|}{ No. accessions } \\
\hline & & 2006 & 2008 & $\begin{array}{l}\text { Rated in } \\
\text { both years }\end{array}$ & $\begin{array}{l}\text { Identical } \\
\text { ratings (\%) }\end{array}$ \\
\hline \multirow{3}{*}{$\begin{array}{l}\text { Leaf-blade margin } \\
\text { serration } \\
\text { (near bottom) }\end{array}$} & 1 = slightly serrate & 19 & 65 & 158 & 62,7 \\
\hline & $2=$ serrate & 136 & 93 & & \\
\hline & $3=$ biserrate & 7 & 1 & & \\
\hline \multirow{4}{*}{$\begin{array}{l}\text { Leaf anthocyanin } \\
\text { intensity (margin } \\
\text { and petiole) }\end{array}$} & $0=$ absent & 46 & 127 & 148 & 29,1 \\
\hline & 1 = weak & 59 & 24 & & \\
\hline & $3=$ strong & 48 & 7 & & \\
\hline & Mixed & 9 & & & \\
\hline \multirow{4}{*}{$\begin{array}{l}\text { Leaf petiole } \\
\text { anthocyanin } \\
\text { intensity }\end{array}$} & $0=$ absent & & & 155 & 49,7 \\
\hline & $1=$ weak & 142 & 74 & & \\
\hline & $3=$ strong & 17 & 85 & & \\
\hline & Mixed & 3 & & & \\
\hline \multirow{3}{*}{ Stem branching } & $1=$ single stalk with no branching & 130 & 131 & 152 & 72,4 \\
\hline & 2 = single stalk with lateral branches & 26 & 28 & & \\
\hline & Mixed & 6 & & & \\
\hline \multirow{4}{*}{$\begin{array}{l}\text { Stem anthocyanin } \\
\text { intensity }\end{array}$} & $0=$ absent & 3 & 17 & 156 & 72,4 \\
\hline & 1 = weak & 45 & 7 & & \\
\hline & $3=$ strong & 114 & 133 & & \\
\hline & Mixed & & 2 & & \\
\hline \multirow{3}{*}{$\begin{array}{l}\text { Stem pubescence } \\
\text { (plant top) }\end{array}$} & $1=$ glabrous & & & 156 & 72,2 \\
\hline & $2=$ intermediate & 32 & 60 & & \\
\hline & $3=$ many hairs & 130 & 99 & & \\
\hline \multirow{7}{*}{$\begin{array}{l}\text { Earliness flowering } \\
\text { (rated in middle of } \\
\text { September) }\end{array}$} & $1=$ maturing & 8 & 4 & 154 & 16,9 \\
\hline & $2=$ end of flowering & 11 & 12 & & \\
\hline & $3=$ full flowering & 38 & 14 & & \\
\hline & $4=$ start of flowering & 56 & 33 & & \\
\hline & $5=$ buds fully developed & 17 & 20 & & \\
\hline & $6=$ start of bud formation & 30 & 21 & & \\
\hline & $7=$ only vegetative & & 50 & & \\
\hline \multirow{3}{*}{$\begin{array}{l}\text { Below-ground } \\
\text { growth }\end{array}$} & $1=$ tubers clustered & 42 & 35 & 157 & 73,9 \\
\hline & $2=$ tubers spreading & 119 & 124 & & \\
\hline & Mixed & 1 & & & \\
\hline \multirow{3}{*}{$\begin{array}{l}\text { Tuber shape } \\
\text { (Modal of 5-10 } \\
\text { tubers) }\end{array}$} & $1=$ round & 84 & 6 & 157 & 41,4 \\
\hline & $2=$ elongated & 63 & 148 & & \\
\hline & $3=$ irregular & 10 & 5 & & \\
\hline \multirow{3}{*}{$\begin{array}{l}\text { Tuber neck } \\
\text { (stolon adherent } \\
\text { to tuber) }\end{array}$} & $1=$ very short, none & 75 & 24 & 157 & 33,1 \\
\hline & $2=$ intermediate & 57 & 100 & & \\
\hline & $3=$ long & 25 & 35 & & \\
\hline \multirow{3}{*}{$\begin{array}{l}\text { Tuber epidermis } \\
\text { thickness }\end{array}$} & $1=$ thin & 79 & 146 & 158 & 51,9 \\
\hline & $2=$ intermediate & 52 & 11 & & \\
\hline & $3=$ thick & 27 & 2 & & \\
\hline \multirow{4}{*}{$\begin{array}{l}\text { Tuber epidermis } \\
\text { anthocyanin } \\
\text { intensity }\end{array}$} & $0=$ absent & 5 & 97 & 158 & 16,5 \\
\hline & $1=$ weak (light red) & 9 & 36 & & \\
\hline & 2 = intermediate (light brown) & 116 & 7 & & \\
\hline & $3=$ strong $($ dark red) & 28 & 19 & & \\
\hline \multirow{4}{*}{$\begin{array}{l}\text { Tuber interior } \\
\text { anthocyanin } \\
\text { intensity }\end{array}$} & $0=$ absent & 104 & 159 & 158 & 65,8 \\
\hline & 1 = weak (light red) & 42 & & & \\
\hline & $2=$ intermediate & 1 & & & \\
\hline & $3=$ strong (dark red) & 11 & & & \\
\hline
\end{tabular}


ments were taken in five replications per accession, i.e., on five different plants (plant height), five leaves or five tubers from each accession. Plant height and leaf measurements were obtained near the end of the vegetation period in September. Leaf measurements were taken from typical, well-developed leaves from the middle part of the stem. Close to the blade the petioles of Jerusalem artichoke are slightly winged, which makes the determination of the exact border between petiole and blade difficult (Figure 2). Therefore, a measurement of the length of the petiole up to the well defined first branching of veins on the blade was conducted. Tuber ratings and measurements were obtained after harvest. Tuber measurements were taken from the five largest tubers of 10-12 tubers randomly harvested from each accession. The data used for this summary originated from the years 2006 and 2008, and from 162 and 159 accessions, respectively, because three accessions were missing in the 2008 nursery. The data are from plantings that were in the second year of growth at the respective location (Figure 1).

Table 2: Variation of qualitative characters in Jerusalem artichoke.

\begin{tabular}{|c|c|c|c|c|c|c|c|c|c|c|}
\hline \multirow{2}{*}{ Character } & \multirow{2}{*}{ Year } & \multirow[t]{2}{*}{ 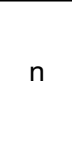 } & \multicolumn{6}{|c|}{ Descriptive statistics } & \multicolumn{2}{|c|}{$\begin{array}{l}\text { Correlation } \\
\text { with } 2008\end{array}$} \\
\hline & & & Min. & Max. & Mean & SD & $\begin{array}{l}\text { CV } \\
\text { (\%) }\end{array}$ & $\begin{array}{l}\text { LSD } \\
\text { (5\%) }\end{array}$ & $r$ & $\mathrm{p}$ \\
\hline Petiole length $(\mathrm{cm})$ & 2006 & 162 & 0.5 & 4.8 & 2.5 & 0.9 & 35.4 & 0.9 & - & - \\
\hline $\begin{array}{l}\text { Length petiole bottom } \\
\text { to first vein branching }(\mathrm{cm})\end{array}$ & 2006 & 162 & 2.2 & 7.3 & 4.5 & 0.9 & 21.1 & 1.0 & - & - \\
\hline $\begin{array}{l}\text { Total leaf length } \\
\text { (petiole + blade) }\end{array}$ & 2006 & 162 & 12.6 & 26.7 & 19.5 & 2.8 & 14.4 & 3.1 & - & - \\
\hline Leaf width & 2006 & 162 & 4.6 & 14.2 & 8.4 & 1.9 & 22.6 & 2.1 & - & - \\
\hline Leaf length/width ratio & 2006 & 162 & 1.5 & 3.5 & 2.4 & 0.4 & 15.7 & 0.9 & - & - \\
\hline \multirow{2}{*}{$\begin{array}{l}\text { Plant height at end of } \\
\text { vegetation period }(\mathrm{cm})\end{array}$} & 2006 & 161 & 119.6 & 202.6 & 161.7 & 16.1 & 10.0 & 20.1 & 0.29 & $<0.1 \%$ \\
\hline & 2008 & 159 & 113.8 & 215.6 & 172.7 & 17.5 & 10.1 & 18.5 & & \\
\hline \multirow{2}{*}{$\begin{array}{l}\text { Tuber length } \\
\text { (excluding neck) (cm) }\end{array}$} & 2006 & 158 & 2.3 & 19.4 & 7.1 & 2.4 & 34.1 & 2.5 & 0.13 & $>5 \%$ \\
\hline & 2008 & 159 & 2.9 & 23.5 & 6.4 & 2.0 & 31.6 & 1.7 & & \\
\hline \multirow{2}{*}{$\begin{array}{l}\text { Tuber width } \\
(\mathrm{cm})\end{array}$} & 2006 & 158 & 1.4 & 6.8 & 3.1 & 1.0 & 33.8 & 1.2 & 0.28 & $<0.1 \%$ \\
\hline & 2008 & 159 & 1.1 & 6.2 & 2.6 & 10.5 & 40.4 & 1.2 & & \\
\hline \multirow{2}{*}{$\begin{array}{l}\text { Tuber length/width } \\
\text { ratio }\end{array}$} & 2006 & 158 & 1.1 & 8.6 & 2.6 & 1.1 & 40.6 & 1.6 & 0.24 & $<1 \%$ \\
\hline & 2008 & 159 & 1.2 & 7.1 & 2.9 & 1.0 & 34.4 & 1.1 & & \\
\hline \multirow{2}{*}{$\begin{array}{l}\text { Single tuber } \\
\text { weight }(\mathrm{g})\end{array}$} & 2006 & 157 & 3.3 & 89.9 & 27.0 & 18.7 & 69.4 & 16.4 & 0.46 & $<0.1 \%$ \\
\hline & 2008 & 159 & 4.0 & 94.6 & 21.2 & 15.0 & 71.0 & 13.0 & & \\
\hline
\end{tabular}

The descriptive results for variability and the correlations among characters reported below were based on observations for 162 accessions from 2006, because in that year more quantitative measurements were completed. Descriptive statistics were applied to summarize the observations. For the quantitative measurements taken on leaves, stems and tubers in five replicated measurements, an analysis of variance was conducted separately for each observation year to calculate a least sig- 


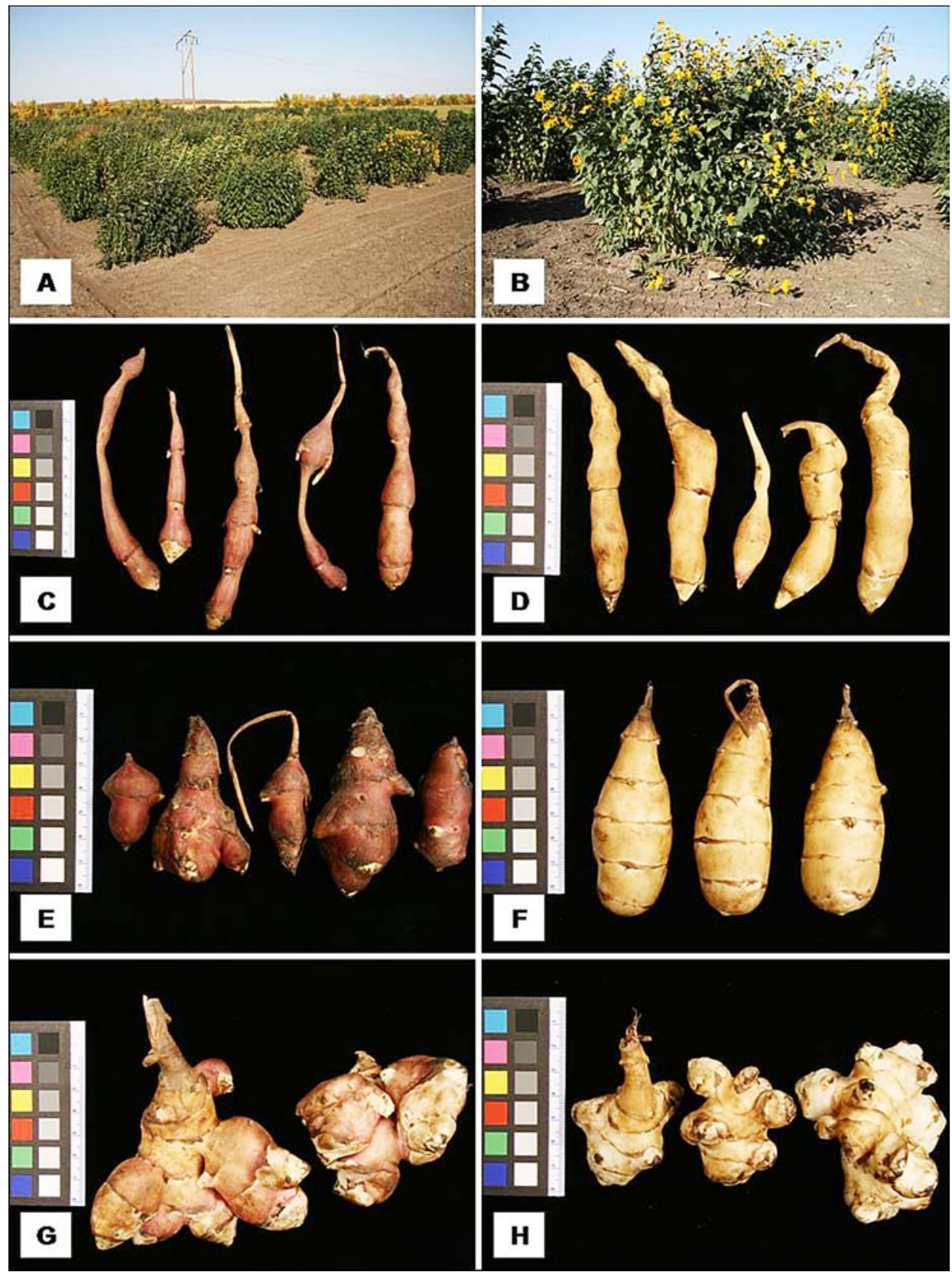

Figure 1: Field plots (A and B) and six tuber types (C-H) of Helianthus tuberosus in the PGRC collection. A: Field nursery in second year. B: Plot in full flowering. $C$ and $D$ : Narrow-elongated tubers. E and F: rounded tubers. G and H: irregular shaped tubers. Shapes in types with red and white epidermis. C: Plot 179 "Jack's Copperclad"; D: NC1O-16; E: "Mansell Sunroot”; NC10-204; G: NC1O-18; H: NC1O-166. 
nificant difference (LSD) at the $5 \%$ level. Histograms were generated to visualize the variability of these quantitative characters. The repeatability of the observations made on each accession in different years was assessed by checking the identity of observations for rated characters or by calculating the linear correlation coefficient for quantitative characters for 158 accessions. The passport data and characterization results for each accession will be published on the PGRC website GRIN-CA (http://pgrc3.agr.gc.ca/).

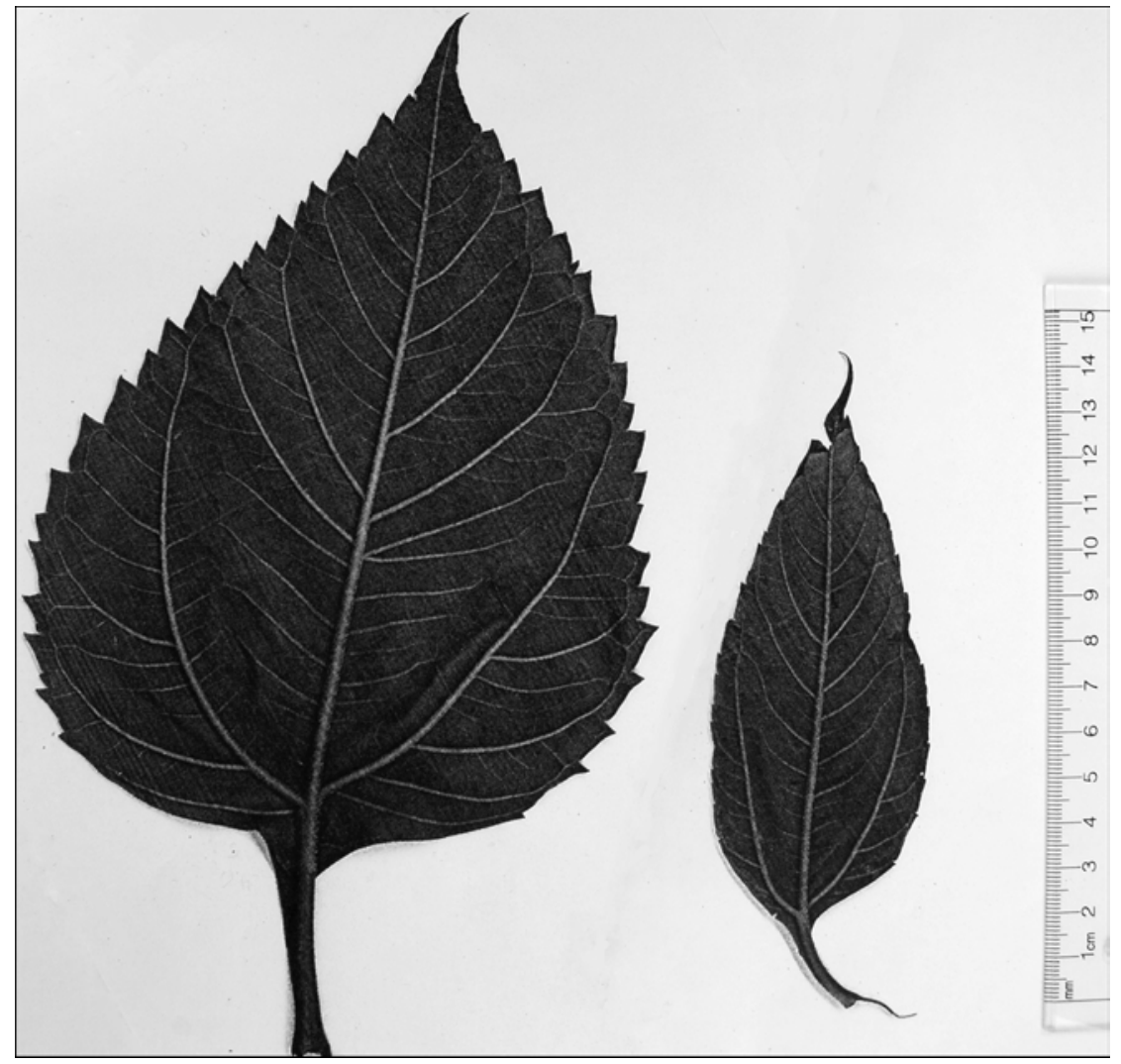

Figure 2: Extremes for leaf margin serration, leaf length and leaf width. Left: NC1O-58; Right: NC1O-44.

\section{RESULTS AND DISCUSSION}

All rated characters (Table 1) and the quantitative characters (Table 2, Figure 3 ) showed considerable variation. High coefficients of variation in both years and the calculated least significant differences at the $5 \%$ level indicated that each quantitative character could be used to distinguish several groups within the range from minimum to maximum value with confidence. 

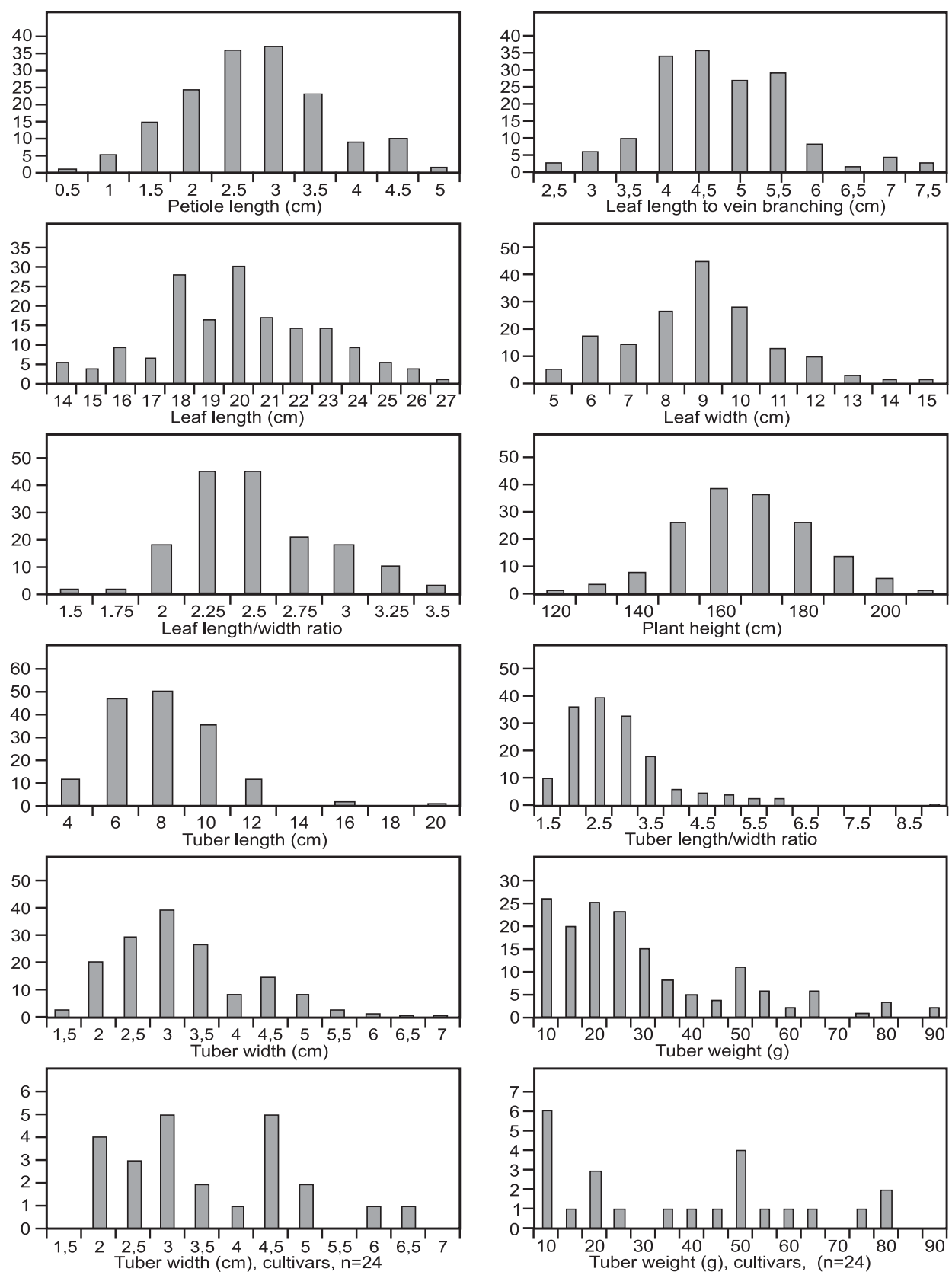

Figure 3: Histograms for quantitative characters based on observations of 162 accessions of Jerusalem artichoke grown at Saskatoon in 2006. The two histograms at the bottom describe the distributions for tuber width and single tuber weight in the 24 cultivars included in the 162 accessions. The vertical axis give the number of accessions in a class and the horizontal axis the upper limit of the classes. 


\section{Leaf characters}

The length of the petiole showed the highest variation of all quantitative leaf characters with a CV of 35.4\%. In five accessions the petiole was shorter than $1 \mathrm{~cm}$, so the leaves were nearly sessile. In 13 accessions the petiole was more than $4 \mathrm{~cm}$ long. The measurements of leaf base to first vein-branching showed continuous variation. Jerusalem artichoke leaves resembled those of sunflower, albeit they only rarely reached the same dimensions commonly seen in sunflowers (Figure 2). Leaf length ranged from 12.6 to $26.7 \mathrm{~cm}$ with an average of $19.5 \pm 2.8 \mathrm{~cm}$. Leaf width ranged from 4.6 to $14.2 \mathrm{~cm}$ with an average of $8.4 \pm 1.9 \mathrm{~cm}$. The ratio of leaf length to leaf width described whether a leaf is narrow or wide. In 19 accessions the ratio was less than 2, indicating broad leaves and in 13 accession the leaves were at least 3 times as long as wide, which characterizes narrow leaves. The histograms of the quantitative leaf characters (Figure 3) showed a normal distribution with only a slight concentration toward the mean value. Assessing the leaf margin serration allowed for distinguishing accessions with only slightly serrated leaves from others with biserrate leaves (Figure 2). While such extreme differences in leaf margin serration could be observed, most accessions were intermediate in this character. Anthocyanin pigmentation was not always visible in the blades, but the petioles showed at least traces of anthocyanin pigmentation in all accessions.

\section{Stem characters}

Only in 28 accessions a lateral stem branching was observed. The upper stem in region of the racemiform inflorescence showed axillary branches in most plants (Figure 1, B). The majority of accessions (114) had strong anthocyanin coloration of the stem. In 45 accessions anthocynanin pigmentation was visible but less obvious. Only three accessions showed no anthocyanin coloration of the stem. Pubescence of the stems was found in all accessions. Plant height ranged in 2006 from 119.6 to $202.6 \mathrm{~cm}$ with an average of $161.7 \pm 16.1 \mathrm{~cm}$. The histogram for plant height showed a normal distribution (Figure 3).

\section{Earliness of flowering}

Close to the end of the vegetation period, which at Saskatoon is due to terminating frosts typically the middle of September, mature seeds could be collected from eight accessions. In these, the above-ground growth was already withering. The other extreme represented 30 accessions in which bud formation had just started at this time. In the cooler growing season of 2008 only four accessions reached maturity and 50 accessions did not reach the stage of bud formation by the middle of September. Earlier accessions tended to be shorter and had heavier tubers (Table 3). Earliness appeared associated with a higher degree of domestication in the plant material when a larger tuber weight was considered as an indication of domestication. Four early maturing accessions of unknown improvement status 
and collected in Canada were the accessions NC103, NC10199, NC1023 and NC10212.

Table 3: Mean values of plant height and single tuber weight for Jerusalem artichoke accessions with different earliness ratings in 2006.

\begin{tabular}{lccc}
\hline Earliness (rated in mid-September) & $\mathrm{n}$ & Plant height $(\mathrm{cm})$ & Tuber weight $(\mathrm{g})$ \\
\hline 1=maturing & 8 & 155.1 & 35.2 \\
2=end of flowering & 11 & 160.9 & 46.5 \\
3=full flowering & 38 & 165.1 & 18.5 \\
4=start of flowering & 56 & 162.8 & 23.9 \\
5=buds fully developed & 17 & 160.4 & 32.3 \\
6=start of bud formation & 30 & 160.1 & 32.3 \\
\hline
\end{tabular}

\section{Below-ground growth}

The rating distinguished 42 types with clustered tubers and 119 with spreading tubers. Tubers with irregular shape (Figure 1, G and H) originated from plants with tightly clustered tubers. The other extreme are plants with elongated stolons and often narrow tubers (Figure 1, C and D) that spread out. Both extremes are problematic from an agronomic viewpoint, as the extremely clustered tubes are difficult to clean of soil while the extremely spreading types are difficult to harvest.

\section{Tuber characters}

Tuber shape rating identified 84 accessions as having round, 63 elongated and 10 irregular tuber shapes. On average, tubers assessed as being round had a tuber length/width ratio of 2.28 , while those assessed as being elongate had an average ratio of 3.32. Round tubers with a length/width ratio close to 1 were rare and only ten accessions had a length/width ratio smaller than 1.5. In 16 accessions, the tubers were at least four times as long as wide (Figure 3).

In some cases the stolons gradually widened to form a tuber, while in other types the stolon more abruptly widened to form a tuber. In the latter case, the neck (adherent stolon) of a tuber was absent or very short ( 75 accessions). Tubers with a long neck were found in 25 accessions. In 57 accessions the neck was of intermediate length. The absolute measurements of tuber length and width showed great variation. The width ranged from 1.4 to $6.8 \mathrm{~cm}$. The tuber length ranged from 2.3 to $19.4 \mathrm{~cm}$. There was, in general, a tendency of wider tubers to be of greater length, but some clones produced long narrow tubers. The correlation coefficient between tuber length and width was $r=0.36$. Tubers longer than $14 \mathrm{~cm}$ were rare and found in three clones (NC 10-43, NC 10-88 and NC 10-173) (Figure 3). Similar to the dimensions, the fresh weight of single tubers also varied greatly. It ranged from 3.3 to $99.9 \mathrm{~g}$. The positive correlation between tuber width and tuber weight was much higher $(r=0.85)$ than between tuber length and tuber weight $(r=0.51)$, underlining that long tubers can be quite narrow and of less weight. All quantitative tuber char- 
acters showed a skewed distribution with concentration towards accessions with small and light tubers (Figure 3).

Tuber epidermis thickness ratings resulted in 79 accessions considered having a thin, 52 an intermediate and 27 a thick epidermis. Klokeid (2002) used this character for distinguishing among four infraspecific groups. This character may be of relevance as it has been suggested that a thin epidermis of Jerusalem artichoke causes dehydration of tubers during storage (Munro and Small, 1997). The coloration of the epidermis is determined by absence or presence of anthocyanins. In five accessions no anthocyanins were observed, nine accessions had some anthocyanins, the majority (116 accessions) were red-brown and 23 accessions had dark red coloration. The tuber flesh can also appear reddish, which may be due to anthocyanin. In eleven accessions such dark red coloration was observed in 2006, yet was absent in the same accessions in 2008. This coloration occurred possibly only after cutting the tubers and may be due to chemical reactions of the injured tissue exposed to air.

\section{Repeatability of observations in the two years}

The repeatability of the rated character assessments was low in all cases. The highest level of identical rating was achieved for below-ground growth and aboveground growth with 73.9 and $72.4 \%$, respectively. These were low levels of repeatability considering the rating scale distinguished only two levels in both characters. Earliness was rated by a scale with seven categories and had a $16.9 \%$ level of repeatability. As this character has a semi-quantitative nature, a correlation coefficient of $r=0.80$ could be calculated between the years. This underlined high repeatability for earliness assessments and the relevance of this character was emphasized by others (Kays and Kultur, 2005). More accessions reached flowering in 2006 than in 2008 which may be explained by a cooler summer in 2008. None of the 28 accessions with stem branching showed such branching in 2008, indicating that this character is not useful for differentiating among accessions at the location Saskatoon, although Pas'ko (1974) and Klokheid (2002) put emphasis on this descriptor. The ratings for anthocyanin presence in the vegetative above-ground plant parts did not allow for any clear and consistent distinctions among accessions. Anthocyanin pigmentation of the stem was more obvious when accessions started flowering. Accordingly, in the warmer growing season of 2006, more accessions reached the flowering stage and more accessions received higher ratings for presence of anthocyanin in the vegetative parts. For distinguishing infraspecific groups this character was not stable enough. Surprisingly, ratings for the presence of anthocyanins in the tubers were also not very consistent. In the cooler season of 2008, many accessions showed less presence of anthocyanins on the tuber epidermis.

The quantitative characters measured in both years showed relatively low coefficients of correlation between the two years (Table 2). The highest repeatability was 
for tuber weight $(r=0.46)$, tuber width $(r=0.28)$ and plant height $(r=0.29)$. Tuber length showed a low repeatability, which is due to environmental influence and inconsistencies in deciding where the tuber neck ends and the tuber begins when measuring its length.

\section{Grouping of the PGRC accessions}

The results indicated a strong environmental influence and a continuous variation for all characters. It is difficult to propose diagnostic characters for repeatable distinction of infraspecific groups. Since the tuber is the traditionally used part of the plant, it is suggested to categorize accessions into large-tuber and primitive types based on tuber weight and tuber size. Measuring tuber length is quite ambiguous due to the poorly defined tuber ends, thus, tuber width may be a better descriptor. Tuber width and tuber weight had the high coefficients of variation (Table 2) and the histograms showed less concentration, i.e., more diversity than characters such as plant height. This and their economic relevance, make these characters suitable for categorizing the variability. A minimum limit for tuber weight of a type worth being cultivated may be $15 \mathrm{~g}$. A minimum tuber diameter may be $2.5 \mathrm{~cm}$. Eighty-eight accessions of the PGRC collection meet both criteria and fell into this category of large-tuber types (Table 4).

Table 4: Number of accessions meeting combined criteria for single tuber weight and tuber width. Based on mean values for two years $(n=158)$.

\begin{tabular}{lcc}
\hline & Tuber weight $>15 \mathrm{~g}$ & Tuber weight $\leq 15 \mathrm{~g}$ \\
\hline Tuber width $>2.5 \mathrm{~cm}$ & 82 (large-tuber type) & 12 (intermediate) \\
Tuber width $\leq 2.5 \mathrm{~cm}$ & 21 (intermediate) & 44 (primitive type) \\
\hline
\end{tabular}

Heavy (more that $60 \mathrm{~g}$ ) and wide tubers were observed in the following three lines: NC10-125 (France) "Kievskij" (former USSR) and "Cambridge" (unknown). Forty-four accessions had lighter $(<15 \mathrm{~g})$ and smaller (width $<2.5 \mathrm{~cm}$ ) tubers, indicating that these are primitive types. Thirty-three accessions met only one of the two established criteria for large-tuber types, so they resembled intermediate types. Six accessions falling in the category of primitive types, had cultivar names. One example is the cultivar "Jack's Copperclad" (Figure 1, E). The proposed grouping is artificial. It may be valid for the environmental conditions at Saskatoon only. Also, there may be accessions collected from the wild, that have large tubers, as in many species that have only a short history and low intensity of domestication wild material is often performing well in cultivation. The 24 cultivars included in this investigation did show a surprising wide range of tuber width and single tuber weights, with a tendency of having a higher frequency of wider and heavier tubers than the entire genepool investigated (Figure 3).

Extremes in tuber variation are shown in Figure 1. Narrow elongated, rounded and irregular shaped tubers occurred in types with red and white epidermis. The continuous variation and the differences in the assessment results between years 
did not allow for a repeatable classification of the accessions into one of the six types shown in Figure 1. However, as an orientation, the six extreme types shown in Figure 1 may be useful when phenotypically assessing the species.

\section{CONCLUSIONS}

While the phenotypic range of diversity observed for rated and quantitative characters in the PGRC collection of Jerusalem artichoke is wide, there is a strong environmental influence on the phenotype. Even the coloration of tubers was not as stable as expected. Earliness, tuber width, tuber weight, tuber shape, tuber epidermis coloration and below-ground growth (clustered tubers vs. spreading ones) seemed the most informative characteristics for describing the variation of Jerusalem artichoke. These characters were relatively repeatable between the two years and are important for utilization. The characterization data available for 159 accessions of Jerusalem artichoke presently preserved by PGRC allows users some orientation about their performance, but a thorough agronomic characterization will be needed in the environment in which the cultivation is planned.

\section{ACKNOWLEDGEMENTS}

I thank Ms. L. Jones-Flory, Ms. D. Nordin, Mr. P. Kusters, Mr. D. Williams, Mr. D. Kessler and several student helpers for establishing and maintaining field plots, data collecting and photographic documentation. The comments made by Drs. K. W. Richards and R.G. St-Pierre on the manuscript were very helpful.

\section{REFERENCES}

Chubey, B.B. and Dorrell, D.G., 1974. Jerusalem artichoke, a potential fructose crop for the prairies. Canadian Institute of Food Science and Technology Journal 7: 98-100.

Frese, L., Schittenhelm, S. and Dambroth, M., 1987. Entwicklung von Basispopulationen bei Wurzel- und Knollenfrüchten zur Erzeugung von Zucker und Stärke als Industriegrundstoffe [Development of base populations from root and tuber crops for the production of sugar and starch as raw material for the industry]. (In German). Lanbauforschung Völkenrode 37: 213-218.

FAO, 2009. World Information and Early Warning System (WIEWS ) on Plant Genetic Resources for Food and Agriculture. http://apps3.fao.org/wiews/wiews.jsp (Accessed on March 18, 2010).

Fuchs, A. [Ed.], 1993. Inulin and inulin-containing crops. Studies in Plant Sciences, Elsevier, Amsterdam 3: 1-417.

Heiser, C.B., 1978. Taxonomy of Helianthus and origin of domesticated sunflower. In: Carter J.F. [Ed.] Sunflower Science and Technology, American Society of Agronomy, Madison, pp. 31-52.

Hergert, G.B., 1991. The Jerusalem artichoke situation in Canada. Alternative Crops Notebook 5: $16-19$.

Joubert, D., 2001. Des plantes indigènes anciennes qui reprennent vie au jardin. [Indigenous plants that regain life in the garden]. (In French). Seeds of Diversity 14(1): 13-17. 
Johnson, R., 2010. Bad boy crop deserves a second chance. Biomass Magazine, January 2010 (http://www.biomassmagazine.com/article.jsp?article_id=3378\&q=\&page =all). (Accessed on March 18, 2010).

Kays, S.J. and Kultur, F., 2005. Genetic variation in Jerusalem artichoke (Helianthus tuberosus L.) flowering date and duration. HortScience 40: 1675-1678.

Kays, S.J. and Nottingham, S.F., 2008. Biology and chemistry of Jerusalem artichoke. Taylor and Francis, Boca Raton.

Kiehn, F. and Chubey B.B., 1993. Variability in agronomic and compositional characteristics of Jerusalem artichoke. In: Fuchs, A. [Ed.] Inulin and Inulin-containing Crops, Studies in Plant Sciences, Elsevier, Amsterdam 3: 1-9.

Klokeid, T.J., 2002. Helianthus tuberosus: Basic taxonomy of the sunroot. Proc. $14^{\text {th }}$ International IFOAM Scientific Conference, August 21-24, 2002, Victoria, Canada.

Le Cochec, F., 1990. Variabilité génétique, heritabilitée et corrélations de 15 caractéres d'une population de clones de topinambour (Helianthus tuberosus L.). (In French). Agronomie 10: 797-806.

Munro, D. and Small, E., 1997. Vegetables of Canada, National Research Council, Ottawa.

Parameswaran, M., 1994. Jerusalem artichoke, turning an unloved vegetable into an industrial crop. Food Australia 46: 473-475.

Pas'ko, N.M., 1974. Selekcija topinambura v SSSR [The breeding of Jerusalem artichoke in the USSR]. (In Russian). Trudy po prikladnoj botanike, genetike i selekcii 53 (1): 231-246.

Pas'ko, N.M., 1987. Sortotipy topinambura [Varietal types of Jerusalem artichoke]. (In Russian). Sbornik nauchnych trudov po prikladnoj botanike, genetike i selektsii 115: 69-75.

Seiler, G.J., 1993. Forage and tuber yields and digestibility of selected wild and cultivated genotypes of Jerusalem artichoke. Agronomy Journal 85: 29-33.

Swanton, C.J., Cavers, P.B., Clements, D.R. and Moore, M.J., 1992. The biology of Canadian weeds, 101, Helianthus tuberosus L. Canadian Journal of Plant Science 72: 1367-1382.

Volk, G.M. and Richards, K., 2006. Preservation methods for Jerusalem artichoke cultivars. HortScience 41: 80-83.

Wein, K., 1963. Die Einführungsgeschichte von Helianthus tuberosus L. [The history of introduction of Helianthus tuberosus L.]. (In German). Kulturpflanze 11: 43-91. 
